\title{
Optimising Material Procurement for Construction Waste Minimization: An Exploration of Success Factors
}

\begin{abstract}
Although construction waste occurs during the actual construction activities, there is an understanding that it is caused by activities and actions at design, materials procurement and construction stages of project delivery processes. This study investigates the material procurement and logistics measures for mitigating waste generated by construction activities. In a bid to explore the phenomenon from the perspectives of experts from the construction industry, this study used a combination of descriptive interpretive research and survey approach as its methodological framework.
\end{abstract}

The study suggests that four features characterised waste efficient logistic and procurement process. These include suppliers' commitment to low waste measures, low waste purchase management, effective materials delivery management and waste efficient Bill of Quantity. In addition, the key requisite strategies for mitigating construction waste through materials procurement include commitment to take back scheme, procurement of waste efficient materials/technology and use of minimal packaging. The use of Just-in-Time (JIT) delivery system and prevention of over ordering are also important for mitigating waste through materials procurement processes. These implies that while the key measures are critical success factors for reducing waste through procurement process, the four established features are required of all procurement process. Measures through which the procurement process could enhance waste efficiency are further highlighted and discussed in the paper. Findings of this study could assist in understanding a set of measures that should be taken during materials procurement process, thereby corroborating waste management practices at design and construction stages of project delivery process.

Keywords: Construction waste; Purchase management; Waste efficient procurement; Landfill; Phenomenology; Materials delivery; Materials take-off.

\section{Introduction}

Owing to the global concerns on environmental sustainability, construction industry has remained a major target for the global sustainability agenda (Anderson and Thornhill, 2002). This is due to an understanding that the industry consumes a higher proportion of mineral resources excavated from nature (Anink et al., 1996), generate substantial portion of atmospheric CO2, and contribute the largest volume of landfill waste (Baek et al., 2013; Ibrahim et al., 2010). For instance, while mining activities, commercial activities, and industrial activities generate $9 \%, 14$ and $13 \%$ of landfill waste in UK respectively, the construction industry generates $44 \%$ of waste 
to landfill (DEFRA, 2013). Due to this, substantial research efforts have been made to understand the causes of waste in construction projects. Earlier investigation of the causes of construction waste is dated as far back as 1976, when Skoyle suggests that materials wastage in the UK construction industry could build as much as 13,000 dwellings a year (Skoyle, 1976; Faniran and Caban, 1998). While the waste generated by the industry has continuously increased, other studies have also investigated the causes of waste in the construction industry (Formoso et al., 2002; Lu and Yuan, 2011; Ikau et al., 2016). These set of studies and industry practices have led to an understanding that waste is generated by activities that are related to project design, materials procurement and actual construction activities.

Notwithstanding the causative impacts of activities in all stages of construction on overall waste generated in construction activities, previous studies have been one sided as significant attention has been paid to construction stage of project delivery process (Osmani et al., 2008; Akinade et al., 2015). Apart from research efforts in this direction, waste management legislations have concentrated on the construction stage, raising the clamour for consideration of other stages with causal influence on construction activities (Baldwin et al., 2009; Umar et al., 2016). This is partly justified, as the actual waste is generated during the important stage of the delivery process. Nonetheless, waste minimization efforts made at other stages could be equally or more important than efforts made during the actual construction stage when such efforts might be late (Osmani et al., 2008; Wang et al., 2014). On a similar note, recent understanding of the significance of design stage on waste generation has engendered research and policy suggestions on measures for designing out waste. It has been argued that a third of construction waste could be reduced through waste minimization efforts made at the design stage of the project delivery process (Innes, 2004). According to Ajayi et al. (2016), this could be achieved by specifying proven techniques for waste minimization.

Despite the fact that literature is rife on the design and construction strategies for minimizing construction waste, there has been less efforts to unravel materials procurement and logistic measures for mitigating waste generated by construction activities. This is notwithstanding the knowledge that the wasted materials are purchased through this process. In addition, Kong et al. (2001) suggests that materials procurement could contribute up to $50 \%$ of project cost. Although, several studies have suggested ineffective coordination of materials procurement process as a key cause of construction waste (Formoso et al., 2002; Ajayi et al., 2017), procurement measures for waste mitigation have either remained unexplored or subjects of scattered and unfocussed findings. Understanding these strategies could significantly reduce waste generated by construction activities, especially as construction activities is so dynamics that activities carried out at one stage would affect the outputs of other stages of the built process (Sterman, 1992; Yuan et al., 2012).

The overall goal of this study is to carry out a detailed exploration of materials procurement and logistics measures for engendering construction waste minimization from practitioners' perspective. In a bid to achieve this aim, the study fulfils the following objectives: 
1. To explore waste efficient measures that could be taken during procurement of construction materials.

2. To determine measures that could be taken by materials suppliers in reducing waste generated by construction activities.

3. To understand how materials delivery process could enhance construction waste mitigation.

In order to gain an in-depth understanding of common experience of industry's experts (Moustakas, 1994), this study employs descriptive interpretive research as its methodological approach. The approach avail an opportunity to bracket out all presuppositions (epoche) and researchers' understanding of the phenomenon under investigation (Creswell, 2013) in search for emic understanding and first-hand information from lived experience of the practitioners (van Manen, 1990). As such, focus group discussions were used as primary means of data collection. The explored factors were then put in a questionnaire survey to determine generalizability of the factors to the construction industry.

As a theoretical insight for this study, the next section provide a review of extant literature in construction waste management. Methodological approach employed in the study, which includes sampling, data collection and analytical procedures are then justified and described. Findings of the study are then presented and discussed before culminating the study with implication for practices and conclusion. The paper offers insights into factors and strategies to be considered during materials purchase and delivery process so as to achieve effective waste management. It would assist construction professionals, materials suppliers and other stakeholders in understanding how well the procurement processes could be coordinated for waste efficiency. It also offer new theoretical insights into the importance of materials procurement in construction waste management.

\section{Construction waste and its management strategies}

Construction industry is an important sector of the global economy that contributes up to $13 \%$ of the economy and employs large percentage of the population (HM Government, 2008). It also serve as a key driver of other sectors, as it provides infrastructure facilities without which other sectors might not be able to operate. However, due to its consumption of large proportion of mineral resources (Baek et al., 2013; Anink et al., 1996) and contribution of large percentage of landfill waste (Ajayi et al., 2015), construction industry has remained a major target for achieving global sustainability agenda (Anderson and Thornback, 2002). In addition, reducing waste generated by construction activities have significant economic benefits. A study by the UK's Building Research Establishment (BRE, 2003) suggests that up to £130million gain could be made by reducing UK construction waste by only $5 \%$. In order to harness this financial benefit and prevent impending environmental problems from waste generation (Oyedele et al., 2014), several research efforts have been made. This section evaluates the research streams in construction waste management. 


\subsection{Research Streams in Construction Waste Management}

Due to a general understanding that problem identification is requisite to solutions, earlier set of construction waste management research were concentrated on causes and source identification. In collaboration with industry experts, these sets of studies employed interviews, questionnaire and case study scenarios to identify that waste is not only induced by activities at construction stages of project delivery (cf. Faniran and Caban, 1998; Ekanayake and Ofori, 2004; Bossink and Brouwers, 1996; Gavilan and Bernold, 1994). Based on various identified causative factors, total waste generation in construction project is caused by series of inter-related factors ranging from design stage, through procurement, to the actual construction stage (cf. Lau et al, 2008; Al-Hajj and Hamani, 2011; Esin and Cosgun, 2007; Formoso et al, 2002; Gamage et al, 2009; Kofoworola and Gheewala, 2009). Although the actual waste is generated on-site during construction activities, a number of preliminary factors contribute to its occurrence. Figure 1 depicts interplay among various causes of waste in construction. This further suggests that holistic efforts towards waste minimization would not look at causes of waste at unitary level; there is need for tackling waste from other stages than construction - planning, design and materials procurement process.

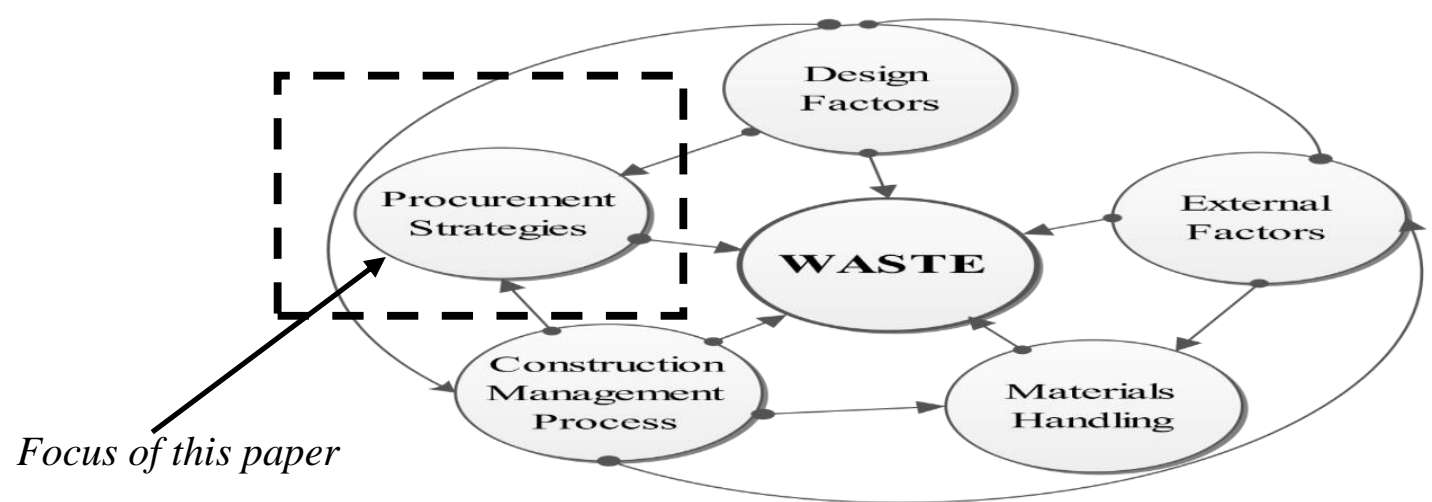

Figure 1: Interplay of Waste Causative Factors Categories

In construction management, some schools of thought believe that waste could not be eradicated. As such, solutions were proffered to waste after it occurred so as to reduce burden on landfill site, thus moving down to lower part of the waste hierarchy. Several research efforts have been made in this perspective, by concentrating on reuse and recycling of waste generated (cf. Medina et al., 2014; Oyedele et al., 2013; Chick and Micklethwaite, 2004; Bolden et al., 2013; Dunster, 2012; Cavalline and Weggel, 2013). Apart from the fact that these set of studies provide end of pipe treatment for waste, the quality of recycled materials has been a subject of controversial literatures. According to Medina et al. (2014), while some studies claim that the quality of concrete reduces with increasing recycled concrete aggregate, others argue that the quality of concrete remains unaffected as a result of recycled aggregate. Additionally, recycling has not been beneficial until the materials are used in further construction activities. However, existing practices suggests that there has been a slow development of recycled materials market (Oyedele et al., 2014). This is because, apart from the lack of 
guaranteed market and conventional specifications for recycled products, designers feel that it requires additional time to source for the products (Sassi and Thompson, 2008).

On a similar note, waste management has also been investigated from the perspectives of minimization and prevention. This category of studies is based on the philosophy that the best approach to waste management is through the use of preventive and minimization strategies. The studies suggest that instead of common industry practices, which concentrates on efforts to manage waste after it is generated, there is tendency of designing out waste during design stage or using some waste efficient strategies during construction stages (Faniran and Caban, 1998; WRAP, 2007; Yuan, 2013). Based on this paradigm, the UK government funded WRAP identified five spectrum through which waste could be effectively designed out. These include design for reuse and recovery, design for offsite construction, design for deconstruction and flexibility, design for materials optimisation, and design for waste efficient procurement (WRAP, 2009a). This paradigm has remained one of the most cost effective and environmental friendly approach to tackling construction waste (Esin and Cosgun, 2007). This is especially as it would reduce the need for materials reuse, recycling and waste disposal thus resulting in more economic and environmental benefits.

Chen and Chang (2000) argue that both planning and design of effective solid waste management system require adequate prediction of likely waste from different sources. As such, a category of study attempted to furnish the industry with tools for predicting likely waste from projects so that preventive measures could be taken to reduce it. Produced by the UK Building Research Establishment (BRE), SMARTWaste is a product of such research efforts towards waste prediction. The study was based on data gathered from previous construction projects, and it estimates and predicts likely waste from projects in 13 categories. It is an online waste management tool that obtains certain information about proposed projects and predicts likely waste from such project based on its statistically-rich database. Solís-Guzmán et al. (2009) also produced a Spanish model based on Andalusian Construction Cost Database. Enriched with data from 100 construction projects, the model is designed for predicting likely waste from projects up to 10 floors. Poon et al. (2001) similarly produced a waste index, which predicts amount of waste (in volume or weight) generated per $\mathrm{m}^{2}$ of gross floor area. The set of studies offers different approaches to waste prediction, and furnished industry practitioners with baseline waste expected from their projects.

Building Information Modelling (BIM) is an emerging technology that is revolutionising the global construction industry. The use of Building Information Modelling is becoming the standard design and simulation platform in the construction industry, using Industry Foundation Class (IFC) as interoperability platform (Porter et al., 2014). Although less effort has been made to incorporate waste minimization into existing BIM tools and platform such as Revit, Micro station, ArchiCAD, and Tekla, attempt has been made to develop BIM tools for waste estimation (Akinade et al., 2016; Bilal et al., 2016). For instance, Cheng and Ma (2013) developed a BIM solution capable of extracting building materials and volume information for detailed waste estimation and 
planning. Despite the limitation of the study to BIM solution for predicting cost of waste disposal, it establishes the tendency for manipulating material ontology of the existing BIM tools or developing BIM interoperable tools towards waste minimization functions. As the wind of BIM adoption continuously blows in the industry, it is expected that more research attention be focussed on the use of BIM technology for waste minimization.

Notwithstanding the advancement in construction waste management research, most efforts have been concentrated on construction stages (Cha et al., 2009; Begum et al., 2007; Al-Hajj and Hamani, 2011). Lately, research into waste efficient design and impacts of design on waste is also gaining popularity (cf. Udawatta et al., 2015; Osmani, 2012; Wang et al., 2015; Osmani et al., 2008). However, despite the understanding that materials procurement process contributes to construction waste generation (Wang et al., 2008; Greenwood, 2003; Lu et al., 2011), strategies for enhancing waste efficient procurement remained less explored. For instance, while studies on reuse and recycling target construction stage, studies on waste prevention, waste prediction and those employing BIM for waste mitigation concentrate on design stage. Few existing procurement measures have only remained a subject of scattered literatures that aimed at reducing waste through design or actual construction activities. As effective procurement process is capable of reducing waste as well as overall cost of construction materials, it is important that research attention is also focussed on waste efficient materials procurement process.

\section{Research Methods}

This study employs sequential exploratory research as its methodological framework. The first section involves focus group discussion with experts within the construction industry, while the second part involves the use of survey to gain wider views of the experts within the industry. This section justifies and discusses the methodological framework for the study.

\subsection{Qualitative data collection}

This study employs qualitative approach in exploring lived experience of industry experts with respect to waste mitigation through materials procurement process. This approach avail the opportunity to interact with information-rich participants in order to gain their common understanding of the phenomenon (Creswell, 2013), rather than the biased understanding of single individual or that of the researcher (Crotty, 1998). The epistemological approach therefore assist in getting first-hand information from industry practitioners (Jasper, 1994), thereby mapping out the procurement strategies for construction waste mitigation.

While carrying out data collection in a qualitative research, in-depth interview with individual participant or interview with multiple participants (focus group discussions) could be employed (Creswell, 2013). In this study, focus group discussions were used as it allows exploration of inter-subjective opinion among the research participant in order to arrive at common understanding of the research participants. In addition, focus group 
discussions was preferred to individual interviews as it allows the participants to build on one another's opinion throughout the course of discussions (Kvale, 1996).

As recommended by Creswell (2013), purposive sampling was used in determining information-rich participants whose understanding is important for the study. As such, selection criteria was based on job position, years of experience, interest in waste mitigation and, of course, willingness and convenience to participate in the study. Researchers' established network of contact within the industry was therefore used in reaching out to the participants. Other studies that have employed this sampling technique within the design and construction management include Akintoye et al. (1998), Oyedele (2013), Ajayi et al. (2015), and Hodgson et al. (2011), among others. However, the group of participants were selected based on critical sampling, which ensures that professions involved from project planning to completion are involved. This sampling technique was used based on Creswell's (1998) assertion that it ensures logical applicability of the finding to other cases. As such, architects, civil/structural engineers, project managers, construction materials suppliers and supply chain managers of construction firms were involved in the focus group discussions.

In line with Polkinghorne's (1989) recommendation that five to 25 information-rich participants are expected to participate in qualitatative research, a total of 24 participants were involved in this study. The participants were selected from across UK design and construction firms ranging from small to large organisation, and they have years of experience ranging from seven to 21 years. The materials suppliers were selected through construction firms, who recommended them as being supportive in waste management efforts. All the participants have been involved in various projects within the last five years and they are committed to waste minimization in construction projects. In addition to two members of the research team that moderated each of the focus group discussions, Table 1 shows the number of participants in each of the discussions.

Table 1: Overview of the focus group discussions and the participants

\begin{tabular}{|c|c|c|c|}
\hline$F G$ & Categories of the Participants & $\begin{array}{l}\text { Total No } \\
\text { of experts }\end{array}$ & $\begin{array}{c}\text { Years of } \\
\text { experience }\end{array}$ \\
\hline 1 & $\begin{array}{l}\text { Architects and Design Managers } \\
\text { - } 2 \text { design architects } \\
\text { - } 3 \text { site architects } \\
\text { - } 2 \text { design managers }\end{array}$ & 7 & $7-18$ \\
\hline 2 & $\begin{array}{l}\text { Materials Suppliers and Supply Chain Managers } \\
\text { - } 4 \text { materials suppliers } \\
\text { - } 2 \text { supply chain managers }\end{array}$ & 6 & $11-21$ \\
\hline 3 & Construction Project Managers & 6 & $10-19$ \\
\hline 4 & $\begin{array}{l}\text { Civil and Structural Engineers } \\
\text { - } 1 \text { design engineer } \\
\text { - } 4 \text { site based engineers }\end{array}$ & 5 & $9-21$ \\
\hline & Total & 24 & \\
\hline
\end{tabular}


Each of the discussions commenced with the need for tackling construction waste, and lasted between 75 and 90 minutes. With due permission from the focus group discussants, the discussions were recorded for the ease of transcription and analysis.

\subsection{Qualitative Data Analysis and Findings}

According to Creswell (2013), qualitative data analysis usually follow a systematic procedure where researcher move from narrow unit of analysis to broader units. As such, analytical process evolve from identification of significant statement to broader units of units. To achieve this, the voice data were transcribed into written statement and read several times to identify significant statements and core themes that explain how the participants were able to mitigate waste through procurement process. This was done through content driven thematic analysis, which seek to explore and identify both implicit and explicit ideas stemming from the data (Braun and Clarke, 2006). According to Moustakas (1994), this process is referred to as "horizonalization". It was then followed the development of clusters of meaning, which forms the basic areas through which construction waste could be mitigated.

In all, a total of four cluster of themes/strategies for mitigating waste through procurement were identified. These are (i) suppliers' low waste commitment, (ii) low waste purchase management, (iii) effective materials delivery management, and (iv) waste efficient bill of quantity. The focus group discussants posit that by addressing the different areas identified, materials procurement process would support waste minimization in construction activities. Table -2 summarises the major waste mitigation strategies identified through the focus group discussions.

Table 2: Materials procurement measure for reducing construction waste

\begin{tabular}{|c|c|c|c|c|c|}
\hline \multirow{2}{*}{ Key Features } & \multirow{2}{*}{ Measures for reducing waste through materials procurement process } & \multicolumn{4}{|c|}{ Focus Groups } \\
\hline & & 1 & 2 & 3 & 4 \\
\hline \multirow{4}{*}{$\begin{array}{c}\text { Suppliers' low } \\
\text { waste } \\
\text { commitments }\end{array}$} & - Suppliers' flexibility in supplying small quantities or modification to products in conformity & & $\checkmark$ & $\checkmark$ & $\checkmark$ \\
\hline & - Commitment to take back scheme (packaging, unused, reusable and recyclable materials) & $\checkmark$ & $\checkmark$ & $\checkmark$ & $\checkmark$ \\
\hline & - Supply of quality and durable products & & $\checkmark$ & $\checkmark$ & $\checkmark$ \\
\hline & - Use of minimal packaging (without affecting materials safety) & $\checkmark$ & $\checkmark$ & $\checkmark$ & $\checkmark$ \\
\hline \multirow{5}{*}{$\begin{array}{l}\text { Low waste } \\
\text { materials } \\
\text { purchase } \\
\text { management }\end{array}$} & - Procurement of waste efficient materials/technology (pre-assembled/cast/cut) & $\checkmark$ & $\checkmark$ & & $\checkmark$ \\
\hline & - Purchase of secondary materials (recycled and reclaimed) & $\checkmark$ & $\checkmark$ & $\checkmark$ & \\
\hline & - Purchase of quality and suitable materials & & & $\checkmark$ & $\checkmark$ \\
\hline & - Avoidance of variation orders & $\checkmark$ & & $\checkmark$ & $\checkmark$ \\
\hline & - Correct materials purchase & $\checkmark$ & $\checkmark$ & & $\checkmark$ \\
\hline \multirow{4}{*}{$\begin{array}{c}\text { Effective } \\
\text { Materials } \\
\text { delivery } \\
\text { management }\end{array}$} & - Effective protection of materials (during transportation, loading \& unloading) & & $\checkmark$ & & $\checkmark$ \\
\hline & - Effective onsite access (for ease of delivery) & $\checkmark$ & $\checkmark$ & $\checkmark$ & \\
\hline & - Efficient delivery schedule & & $\checkmark$ & $\checkmark$ & $\checkmark$ \\
\hline & - Use of Just in Time delivery system & $\checkmark$ & $\checkmark$ & $\checkmark$ & $\checkmark$ \\
\hline \multirow{3}{*}{$\begin{array}{c}\text { Waste efficient } \\
\text { Bill of } \\
\text { Quantity }\end{array}$} & - Accurate materials take-off & $\checkmark$ & & $\checkmark$ & \\
\hline & - Prevention of over/under ordering & & $\checkmark$ & $\checkmark$ & \\
\hline & - Reduced waste allowance & $\checkmark$ & $\checkmark$ & $\checkmark$ & $\checkmark$ \\
\hline
\end{tabular}




\subsection{Quantitative Data Collection and Analysis}

In order to elicit wider practitioners' view of the qualitatively explored factors, the established measures were operationalised into a questionnaire survey. This provides an opportunity of reaching out to larger audience within a short period, and in a cost effective manner (Creswell, 2013). Construct and face validity of the research instrument was ensured through a pilot test, which involved two site waste managers, two construction project managers and two site managers. Based on the issues raised, the questionnaire was improved before it was sent to respondents. Using the list of the top 100 construction companies and directories of three professional bodies as a sampling frame, 200 questionnaires were sent to the participants. The three professional bodies were the Association of Project Managers (APM), Chartered Institute of Buildings (CIOB) and Chartered Institute of Waste Managers (CIWM). After a number of reminders, a total of 127 responses were received, yielding a response rate of $63.5 \%$. Distribution of the respondents is shown in table 3.

Table 3: Overview of quantitative research respondents

\begin{tabular}{|c|c|}
\hline Profession/Job roles & Sample size \\
\hline Site Manager/Engineer & 32 \\
\hline Project Managers & 52 \\
\hline Site waste managers & 43 \\
\hline Total & 127 \\
\hline Years of Experience & \\
\hline $0-5$ & 7 \\
\hline $6-10$ & 21 \\
\hline $11-15$ & 41 \\
\hline $16-20$ & 28 \\
\hline $21-25$ & 19 \\
\hline 26 and Above & 11 \\
\hline Total & 127 \\
\hline
\end{tabular}

As recommended by Nunnally and Bernstein (2007), internal consistency of criteria contained in the questionnaire as well as the suitability of the data for analysis was evaluated using Cronbach's Alpha, which is given as:

$$
\alpha=\frac{N^{2} \overline{\mathrm{COV}}}{\sum_{i=1}^{N} S_{i}^{2}+\sum_{i=1}^{N} \operatorname{COV}_{i}}
$$

Where $N$ is the total number of factors; $\overline{C O V}$ is the average covariance between factors; $S_{i}^{2}$ and $\operatorname{COV}_{i}$ are the variance and covariance of factor ' $i$ ' respectively.

A Cronbach Alpha value of 0.7 represents an acceptable consistency, while 0.8 indicates a good internal consistency according to Field (2009). Using SPSS version 22, the Cronbach's alpha coefficient for this study is 0.91 . This suggests an excellent reliability and internal consistency of the items on the questionnaire. In order 
to confirm whether all items on the questionnaire are contributing to the good internal consistency, "Cronbach's alpha if item deleted" were evaluated as suggested by Field (2009). In this case, any item with Cronbach's alpha above the established value of 0.91 means that such item is not a good construct and should be deleted from the list of variables. As shown in table 4, only one variable (Correct materials purchase) has its value above 0.91 and it is therefore removed from further analysis. On deleting the outlier, the Cronbach's alpha coefficient improved to 0.93 . As a means of establishing the key procurement and logistics measures for waste mitigation, descriptive statistics was carried out. The ranking and analysis was based on the importance index of the Likert scale that ranges from 1-5, where 1 represents not important and 5 represents most important. Table 4 shows the means as well as the level of significance of each of the established measures.

Table 4: Descriptive statistics and ranking of logistics measures for waste mitigation.

\begin{tabular}{|l|r|r|r|}
\hline \multicolumn{1}{|c|}{ Measures for reducing waste through materials procurement process } & $\begin{array}{l}\text { Mean } \\
\text { Value }\end{array}$ & $\begin{array}{r}\text { Rank } \\
\text { 1. Suppliers' flexibility in supplying small quantities or modification to products in } \\
\text { conformity with designs }\end{array}$ & $\begin{array}{r}\text { Cronbach alpha if } \\
\text { item deleted }^{* * *}\end{array}$ \\
\hline 2. Commitment to take back scheme (packaging, unused, reusable and recyclable materials) & 4.52 & 8 & 0.90 \\
\hline 3. Supply of quality and durable products & 3.72 & 12 & 0.74 \\
\hline 4. Use of minimal packaging (without affecting materials safety) & 4.33 & 3 & 0.90 \\
\hline 5. Procurement of waste efficient materials/technology (pre-assembled/cast/cut) & 4.41 & 2 & 0.85 \\
\hline 6. Purchase of secondary materials (recycled and reclaimed) & 3.11 & 15 & 0.80 \\
\hline 7. Purchase of quality and suitable materials & 3.60 & 13 & 0.89 \\
\hline 8. Avoidance of variation orders & 3.88 & 11 & 0.89 \\
\hline 9. Correct materials purchase ${ }^{* * * *}$ & & & 0.88 \\
\hline 10. Effective protection of materials (during transportation, loading \& unloading) & 3.98 & 7 & $\mathbf{0 . 9 3}$ \\
\hline 11. Effective onsite access (for ease of delivery) & 3.89 & 10 & 0.90 \\
\hline 12. Efficient delivery schedule & 3.51 & 14 & 0.88 \\
\hline 13. Use of Just in Time delivery system & 4.32 & 4 & 0.85 \\
\hline 14. Accurate materials take-off & 3.93 & 0.86 \\
\hline 15. Prevention of over/under ordering & 4.19 & 5 & 0.83 \\
\hline 16. Reduced waste allowance & 4.00 & 6 & 0.76 \\
\hline
\end{tabular}

$a^{* *:}$ Overall Cronbach Alpha coefficient is 0.91

$b^{* * *}$ Item was deleted from the data as it is not adequately contributing to overall reliability of the data

\section{Discussions}

The section discusses the findings of the study in two sections. The first section discusses the underlying measures for mitigating waste through materials procurement, while the second section discusses the key logistic measures for minimizing waste generated by construction activities. 


\subsection{Key underlying themes for mitigating waste through materials procurement}

The materials procurement measures for waste minimization are discussed under four categories as shown in Table -2 . According to the focus group discussants, the four broad measures that are requisite for reducing waste through materials procurement processes are (i) suppliers' attributes and commitment, (ii) materials purchase management, (iii) materials delivery management, and (iv) design compliant procurement. These broad strategies are further discussed in the following sub-sections.

\subsubsection{Suppliers/Vendors' Low Waste Commitment}

Materials manufacturers and suppliers are important stakeholders in the construction industry. Owing to their contribution to the industry, most literature often place them at equal level as such stakeholders like designers, waste managers and contractors (Adams et al., 2011). Apart from their central role in the industry, some studies have pointed to their role in reducing waste intensiveness of the construction industry (Ajayi et al., 2015). As such, the extent to which materials purchase and suppliers' commitment could assist in reducing construction waste could not be overemphasised. This belief was similarly shared by the research participants who argued that:

\footnotetext{
"When we are talking of waste reduction, the materials suppliers and manufacturers are very key in finding solution.....in most cases, they are part of the problem....and they could be really helpful". "They could help in reducing offcut waste by assisting in materials modification to suit the required size...although this could be costly, but we did it in one project where waste was a KPI and it was really helpful. We had less offcut, which means less landfill waste".
}

Meanwhile, a common cause of waste on construction site is excessive stocking of materials, which could result in breakage (Del Río Merino et al. 2009). In such instance, supplier that is flexible in providing small quantity of materials, when required, could assist in reducing waste. This claim by the focus group discussants further confirms earlier suggestion by Dainty and Brooke (2004), who posit that flexibility of materials suppliers in providing small quantities is requisite to reducing waste generated by construction activities.

Another measure through which readiness of materials suppliers for waste mitigation could be ascertained is their commitment to take back scheme. It involves a mutual agreement between project team and suppliers, so that the latter would take back unused materials at the end of construction activities. The respondents echoed that:

"The materials suppliers are very key in decisions with respect to take back scheme.... most of the waste we generate onsite are due to materials left unused after the projects. You will not only 
reduce waste if you have take-back agreement with your suppliers, you will also save some money.

That's if you are lucky enough to get them into agreement"

In line with above recommendations, literatures have suggested take back scheme as a means of reducing waste due to materials leftover (Osmani et al., 2008; Oyedele et al., 2013). As such, it is important that materials suppliers be committed to take back scheme as a means of getting the reusable materials back to the market. Overall, this study suggests that commitment and support of materials supplier is a key requisite for achieving waste minimization in construction projects.

\subsubsection{Low Waste Materials Purchase Management}

As materials could contribute up to $50 \%$ of project cost (Kong et al., 2001), success and profitability of a construction project largely depends on the extent to which its materials purchase is effectively managed. This means that effective coordination of materials purchase is not only required for waste mitigation, it is also important for overall success of the project. Meanwhile, Tam (2008) identified purchase management as an effective measure for reducing waste in construction projects. Other studies have pointed out various measures through which materials purchase could be adequately used to reduce waste. It is important that activities that could lead to wrong materials purchase be addressed before actual materials ordering (Bernold et al., 1991; Muhwezi et al., 2012). While deliberating on the importance of material procurement process, the focussed group participants argued that:
"Materials purchase is a decisive step that determine the level of waste that would be eventually generated in construction projects....It is important that waste preventive measures are taken during the process". A procurement process that favours the use of prefabricated materials instead of in-situ materials will enhance waste reduction...II materials are pre-cut, offcut waste would also be prevented to a great extent.

While materials optimization should be carried out to avoid over ordering, under ordering and excess waste allowance (Begum et al., 2007; Hassan et al., 2012), adequate considerations should also be given to the nature of materials purchased. Strong indication emerged that quality and reusability of the materials would ensure its longevity and conservation of mineral resources respectively. This corroborates earlier findings that the use of low quality construction materials is a major cause of incessant renovation and its subsequent waste generation (Dainty and Brooke, 2004). In addition, reusability of packaging materials will reduce waste output of the project, especially as packaging waste constitutes substantial proportion of construction waste (Esin and Cosgun, 2007; Wang et al., 2008). 
On a similar note, the discussants posit that:

...If we are recycling materials without using them in other projects, it will not benefit the environment and we have not reduced no waste".

This is in agreement with earlier studies, which suggest that specification and subsequent use of recycled materials is indispensable to waste minimization and the overall global sustainability agenda (Oyedele et al., 2014). Based on this, there is need to procure secondary materials and support reuse of existing materials (Begum et al., 2009). To develop markets of recycled materials and divert waste from landfill, it is expected that materials with higher recycled content be always considered. This is important for reducing waste output of the construction industry.

\subsubsection{Effective Materials Delivery Management}

The extent to which adequate planning is made for materials delivery goes a long way in determining waste outputs of the project. Suppliers, site managers and other stakeholders have roles to play in ensuring that breakage to materials is prevented during delivery activities. In agreement with earlier studies (Hassan et al., 2012), the focus group discussants suggest that loosely supplied materials should be avoided while seeking to prevent breakage and its subsequent waste generation. It was stressed that:

"Although materials are expected to be well packaged and protected..., we should also avoid too much packaging ....as the packaging materials also contributes a large percentage of waste on sites".

During loading, transportation and unloading, damages could be prevented through sufficient protection of the materials (Garas et al. 2010), which should also be devoid of over-packaging (Oyedele et al., 2013). As such, moderation is expected to be achieved between what could be termed as "inadequate packaging" and "overpackaging", both of which are known causes of waste.

It was also noted that:

"Apart from the breakage that is usually caused by materials suppliers (...which is sometimes replaced for us), some of these materials breakages are caused by poor site access.... Most breakages occur by the time the delivery truck is trying to navigate narrow site access.....addressing this aspect is key to waste effective materials delivery"

Owing to this, it is important that site access be well planned, as it helps in reducing materials breakage (Osmani et al., 2008). 
In line with existing studies (Ballard and Howard, 1997; Al-Hajj and Hamani, 2011; Marinelli et al., 2014), the focus group discussants posit that Just in Time (JIT) procurement is a waste efficient materials procurement process. It was stressed that:

"JIT delivery process is very efficient in reducing materials waste. It prevents excessive stocking of materials, which usually lead to breakage and waste.... Most of us do not use JIT because it is cheaper to transport your materials in bulk. But if you estimate the cost of waste it prevented, you will realise that it is a better option... you only need to be careful so that it will not delay your activities".

The JIT is a pull system of procurement, where materials are ordered as at when needed during the construction process. It is different from the push system, where materials are ordered in bulk, leading to over-stocking of materials and longer period of onsite storage. By using the pull process (JIT), the materials are only taken to site when they are needed, thereby preventing excessive storage of the materials (Khanh and Kim, 2014). It would as well prevent waste that could be due to stock piling, inefficient handling and materials leftover.

\subsubsection{Waste Efficient Bill of Quantity}

A proven way of minimizing waste generated by construction activities is to ensure that ordered materials is devoid of over/under ordering. Within the industry, it has become a norm that a certain proportion of materials is added as a waste allowance. According to Buchan et al. (1991), this allowance is usually in the range of 2.5 to $10 \%$ of the quantity of materials. Apart from this clear source of materials waste, it was stressed that:

“.. most procurement processes failed to follow what have been specified in design documents"... and what do you see as the outcome?...it is usually over ordering and materials wastage.."

As pointed out, materials procurement in defiance of design is a major cause of under/over ordering, or what could be generally termed as inaccurate ordering (Faniran and Caban, 1998). It is therefore important that materials take-off is accurately done in preparation for actual materials purchase (Muhwezi et al., 2012; Nagapan et al., 2013). This is then expected to be followed up by materials ordering that is devoid of over or under ordering.

\subsection{Critical Procurement Measures for waste mitigation}

This section discusses the top-rated strategies for preventing waste through materials procurement and logistics. 


\subsubsection{Commitment to Take Back Scheme}

The finding suggests that the most important procurement and materials logistics measures for preventing waste is the take back scheme, which is a mutual agreement between project team and suppliers, so that the latter would take back unused materials at the end of construction activities. Through this agreement, waste due to materials leftover would be significantly reduced. According to Osmani et al. (2008) and Oyedele et al. (2013), materials leftover constitutes significant proportion of total waste generated by construction activities. Thus, flexibility of suppliers in taking back unused materials (Dainty and Brooke, 2004), recyclable materials (Cha et al., 2009), and packaging materials from construction sites are good measures of the extent to which suppliers support waste reduction. Due to this, it is evident that commitment to take back scheme is not only a means of getting the reusable materials back to the market, it is capable of reducing the volume of waste landfilled by the construction industry.

\subsubsection{Procurement of Waste Efficient Materials/Technology}

Procurement of waste efficient materials is ranked as a top logistic strategy for mitigating waste generated by construction activities. This could be in forms of materials that supports low waste output, use of modular element or pre-cut materials that reduces the waste that could be due to materials offcut and in-situ elements. This was also echoed by Formoso et al. (2002) who argued that materials procurement that support pre-cut and precast materials is indispensable to waste effectiveness of the construction industry. According to Tam et al (2007), the use of precast materials is capable of reducing waste generated by construction activities by up to $84.7 \%$. As such, the use of such construction techniques as modular technologies, prefabrication elements and cut to fit materials are indispensable to reducing waste generated by construction activities.

\subsubsection{Use of Minimal Packaging}

Another top logistic measure for diverting waste from landfill is the use of minimal packaging for construction materials. As packaging waste constitutes a substantial proportion of construction waste (Yeheyis et al., 2013; Saez et al., 2011), it is expected that materials suppliers should support procurement routes that minimizes packaging waste. This will help in preventing a major cause of waste in construction projects. Nonetheless, it is expected that balance is reached between what could be termed as minimal and inadequate packaging, as the latter is also capable of inducing materials breakage.

\subsubsection{Use of Just in Time (JIT) Delivery System}


A key procurement strategy for minimizing construction waste is the use of Just in Time delivery route, which ensures that materials are delivered to the site in batches when they are needed. This helps in reducing the length of time the materials are stored as well as eliminating the likelihood of over-ordering and double handling, which usually results in breakages (Dainty and Brooke, 2004). Another key benefit of the use of JIT delivery system is its likelihood of preventing double handling of materials, which is a known cause of materials breakage and subsequent waste generation (Al-Hajj and Hamani, 2011). Equally, JIT is a very valuable measure in confined sites, where there is no adequate space for materials storage. As preventing waste due to double handling and materials leftover, the use of JIT delivery system is a key logistic strategy for preventing waste generated by construction activities.

\subsubsection{Prevention of Over Ordering}

Over ordering is a major cause of materials leftover and subsequent waste generation in construction projects (Faniran and Caban, 1998). This is usually due to mistakes made in quantity estimates, poor delivery schedule or as a result of deliberate waste allowance that is added to ordered materials (Begum et al., 2007; Hassan et al., 2012). In line with the established impacts of over ordering on materials waste, this study suggests the need for preventing over ordering as a requisite for mitigating waste generated by construction activities. This could be achieved by reducing waste allowance, which is usually in the range of $2.5-10 \%$ of the quantity of total materials required for construction activities (Buchan et al., 1991). It is equally important that quantity estimates be accurately carried out in order to prevent inadequate ordering.

\section{Conclusion}

Previous studies on strategies for mitigating construction waste have concentrated on the design and actual construction stages, leaving out the strategies for preventing waste through materials procurement and logistics process. As a means of filling the gap in knowledge, and complementing the design and construction strategies for waste mitigation, this study explores the procurement and logistics measures for construction waste minimization. In order to explore the measures from practitioners' point of view, a qualitative approach was used at the first stage of the study, while survey research was used to identify the key logistics strategies for waste mitigation. The study shows that suppliers' commitment to low waste measures, low waste purchase management, effective materials delivery management and waste efficient Bill of Quantity are key features that characterised waste efficient procurement processes. In addition, the top key strategies for mitigating construction waste through materials procurement include commitment to take back scheme, procurement of waste efficient materials/technology, use of minimal packaging, use of Just-in-Time (JIT) delivery system and prevention of over ordering. 
This study has implication for both construction practices and research into construction waste management. At the industry level, it is important that waste management effort is also made at other stages of project delivery process in similar way as efforts is being made at the construction stage. More importantly, as materials procurement could contribute up to $50 \%$ of project cost, it is expected that waste preventive measures be taken when preparing for materials purchase as well as during its purchase and delivery process. This could be achieved through the measures categorised as waste efficient purchase management, design compliant procurement, and waste efficient delivery management. Readiness of materials' suppliers for collaborative waste mitigation could be evaluated through their commitment to such arrangement as take back scheme, flexibility in supplying small quantities of materials and proportion of secondary materials in their products, all of which are important for diverting construction waste from landfill. These set of measures could therefore be used in benchmarking the suppliers in projects where waste reduction is a key performance indicator. By delivering materials as at when needed, breakage due to doubles handling as well as materials leftover would be prevented. Rather than concentrating on design and construction stages, research into waste management is expected to consider other stages of project delivery process. This is particularly important for procurement process as this study suggests that procurement process is important in reducing waste intensiveness of the construction industry.

With paucity of research into waste efficient materials procurement process, this study has been limited to exploration of factors required for reducing waste through the process. Owing to this, the study has concentrated on depth of findings rather than length. Generalizability of its findings and identified factors could be investigated through more explanatory approach. Transferability of the findings of this study to other nations than the UK, where its data was collected, could be explored by other studies.

\section{References}

Adams, K., Johnson P., Thornback, J., \& Law C., (2011). An Action Plan for halving construction, demolition and excavation waste to landfill. UK: WRAP.

Ajayi, S.O., Oyedele, L.O., Akinade, O.O., Bilal, M., Owolabi, H.A., and Alaka, H.A. (2014). Ineffectiveness of construction waste management strategies: Knowledge gap analysis. In: Okeil, M. (2014). Smart, sustainable and healthy city, Proceedings of the First International Conference of the CIB Middle East and North Africa Research Network (CIB-MENA 2014), pp. 261 - 280.

Ajayi, S.O., Oyedele, L.O., Bilal, M., Akinade, O.O., Alaka H.A., Owolabi, H.A., and Kadiri, K.O. (2015). Waste Effectiveness of the Construction Industry: Understanding the Impediments and Requisites for Improvements. Resources, Conservation and Recycling. Accepted manuscript in press. 
Ajayi, S.O., Oyedele, L.O., Bilal, M., Akinade, O.O., Alaka, H.A. and Owolabi, H.A., 2017. Critical management practices influencing on-site waste minimization in construction projects. Waste Management, 59, pp. 330 - 333.

Akinade, O.O., Oyedele, L.O., Bilal, M., Ajayi, S.O., Owolabi, H.A., Alaka, H.A. and Bello, S.A., 2015. Waste minimisation through deconstruction: A BIM based Deconstructability Assessment Score (BIMDAS). Resources, Conservation and Recycling, 105, pp.167-176.

Akinade, O.O., Oyedele, L.O., Munir, K., Bilal, M., Ajayi, S.O., Owolabi, H.A., Alaka, H.A. and Bello, S.A., 2016. Evaluation criteria for construction waste management tools: towards a holistic BIM framework. International Journal of Sustainable Building Technology and Urban Development, pp.1-19.

Al-Hajj, A., \& Hamani, K. (2011). Material Waste in the UAE Construction Industry: Main Causes and Minimization Practices. Architectural Engineering and Design Management, 7(4), pp. 221 - 235.

Ameh, O.J., \& Itodo, E.D. (2013). Professionals' views of material wastage on construction sites and cost overruns. Organization, Technology \& Management in Construction: An International Journal, 5(1), 747-757.

Anderson, J., \& Thornback, J. (2012). A guide to understanding the embodied impacts of construction products. London: CPA.

Anink, D., Mak, J., \& Boonstra, C. (1996). Handbook of Sustainable Building: An Environmental Preference Method for Selection of Materials for Use in Construction and Refurbishment. London: James and James.

Baek, C., Park, S., Suzuki, M. \& Lee, S. (2013). Life cycle carbon dioxide assessment tool for buildings in the schematic design phase. Energy and Buildings, 61(2013), 275-287

Baldwin, A., Poon, C.S., Shen, L.Y., Austin, S. and Wong, I., 2009. Designing out waste in high-rise residential buildings: Analysis of precasting methods and traditional construction. Renewable energy,34(9), pp.2067-2073.

Ballard, G., \& Howell, G. (1997). Construction JIT. In: Alarcon, L., (ed.) Lean Construction. Rotterdam, Netherlands: AA Balkema.

Begum, R. A., Siwar, C., Pereira, J. J., \& Jaafar, A. H. (2007). Implementation of waste management and minimisation in the construction industry of Malaysia. Resources, Conservation and Recycling, 51(1), pp. 190-202.

Begum, R. A., Siwar, C., Pereira, J. J., \& Jaafar, A. H. (2009). Attitude and behavioral factors in waste management in the construction industry of Malaysia. Resources, Conservation and Recycling, 53(6), pp. 321-328.

Bernold, L. E., \& Treseler, J. F. (1991). Vendor analysis for best buy in construction. Journal of Construction Engineering and Management, 117(4), pp. 645-658.

Bilal, M., Oyedele, L.O., Qadir, J., Munir, K., Akinade, O.O., Ajayi, S.O., Alaka, H.A. and Owolabi, H.A., 2016. Analysis of critical features and evaluation of BIM software: towards a plug-in for construction waste minimization using big data. International Journal of Sustainable Building Technology and Urban Development, pp.1-18. 
Bolden, J., Abu-Lebdeh, T., \& Fini, E. (2013). Utilization of recycled and waste materials in various construction applications. American Journal of Environmental Sciences, 9(1), pp. 14-24

Bossink, B., \& Brouwers, H. (1996). Construction Waste: Quantification and Source Evaluation. Journal of Construction Engineering Management, 122(1), pp. 55 - 60.

Braun, V., and Clarke, V. (2006). Using thematic analysis in psychology. Qualitative research in psychology, 3(2), pp. 77-101.

BRE, (2003). Construction and demolition waste: Good buildings guide 57 Part 1. UK: Building Research Establishment.

Browna, Z.S., and Johnstone, N., 2014. Better the devil you throw: Experience and support for pay-as-youthrow waste charges. Environmental science and policy, 38(2014), pp. 132-142

Buchan, J.D., Fleming, F.W. and Kelly, J.K., 1999. Estimating for builders and quantity surveyors. Butterworth Heinemann.

Buchan, R. D., Fleming, F. W., \& Kelly, J. R. (1991). Estimating for builders and quantity surveyors. Oxford: Newnes.

Cavalline, T.L., \& Weggel, D.C. (2013). Recycled brick masonry aggregate concrete: Use of brick masonry from construction and demolition waste as recycled aggregate in concrete. Structural Survey, 31(3), pp. $160-180$.

Cha, H. S., Kim, J., \& Han, J. Y. (2009). Identifying and assessing influence factors on improving waste management performance for building construction projects. Journal of Construction Engineering and Management, 135(7), pp. 647-656.

Chen, H. W., \& Chang, N. B. (2000). Prediction analysis of solid waste generation based on grey fuzzy dynamic modeling. Resources, Conservation and Recycling, 29(1), pp. 1-18

Cheng, J.C.P., and Ma, L.Y.H. (2013). A BIM-based system for demolition and renovation waste estimation and planning, Waste Management, 33(2013), pp. 1539-1551

Chick, A., and Micklethwaite, P. (2004). Specifying Recycled: Understanding uk architects and designers practices and experience. Design studies, 25(3), pp. 251 - 273.

Creswell, J. W. (2013). Qualitative inquiry and research design: Choosing among five approaches, $3^{\text {rd }}$ edition. Thousand Oaks: Sage.

Dahlén, L., and Lagerkvist, A., 2010. Pay as you throw Strengths and weaknesses of weight-based billing in household waste collection systems in Sweden. Waste Management, 30(1), pp. 23-31

Dainty, A.R.J., \& Brooke, R.J. (2004). Towards improved construction waste minimisation: A need for improved supply chain integration? Structural Survey, 22(1), pp. 20-29.

Del Río Merino, M., Azevedo, I. S. W., \& Gracia, P. I. (2009). Sustainable construction: construction and demolition waste reconsidered. Waste management and research, 28(2), pp. 118-129.

Dunster, A. (2012). The use of recycled and secondary materials in residential construction. Milton Keynes: NHBC Foundation. 
Ekanayake, L.L., \& Ofori, G. (2004) Building waste assessment score: Design-based tool. Building and Environment, 39(7), pp. 851-861.

Esin, T., \& Cosgun, N., (2007). A study conducted to reduce construction waste generation in Turkey. Building and Environment, 42(4), pp. 1667-1674.

Faniran O.O, \& Caban G. (1998). Minimizing waste on construction project sites. Engineering, Construction and Architectural Management, 5(2), pp. 182-188.

Formoso, C.T., Soibelman, L., De Cesare, C., \& Isatto, E.L. (2002). Material Waste in Building Industry: Main Causes and Prevention. Journal of Construction Engineering and Management, 128(4), pp. 316 - 325.

Gamage, I.S.W., Osmani, M., \& Glass, J. (2009). An investigation into the impact of procurement systems on waste generation: The contractors' perspective In: Dainty, A. (Ed). Proceedings of 25th Annual ARCOM Conference, 7-9 September 2009, Nottingham, UK.

Garas, G. L., Anis, A. R., \& El Gammal, A. (2001). Materials waste in the Egyptian construction industry. Proceedings of the 9th Annual Conference of the International Group for Lean Construction, National University of Singapore, Singapore, 2001

Gavilan, R. M., \& Bernold, L. E. (1994). Source evaluation of solid waste in building construction. Journal of Construction Engineering and Management, 120(3), pp. 536-552.

Greenwood, R. (2003). Construction Waste Minimisation: Good Practice Guide. Cardiff University, Centre for Research in the Built Environment.

Hassan, S. H., Ahzahar, N., Fauzi, M. A., \& Eman, J. (2012). Waste Management Issues in the Northern Region of Malaysia. Procedia-Social and Behavioral Sciences, 42(2012), pp. 175-181.

HM Government (2008). Strategy for sustainable construction. London: Department for Business, Enterprise and Regulatory Reform

Ibrahim, A.Z., Roy, M.H., Ahmed, Z.U. \& Imtiaz, G. (2010). Analysing the dynamics of the global construction industry: Past, present and future. Benchmarking: An International Journal, 17(2), $232-252$.

Ikau, R., Joseph, C. and Tawie, R., 2016. Factors Influencing Waste Generation in the Construction Industry in Malaysia. Procedia-Social and Behavioral Sciences, 234, pp.11-18.

Innes, S. (2004). Developing tools for designing out waste pre-site and onsite. In: Proceedings of Minimising Construction Waste Conference: Developing Resource Efficiency and Waste Minimisation in Design and Construction, New Civil Engineer, London, UK, October 2004.

Khanh, H.D., \& Kim, S.Y. (2014). Identifying Causes for Waste Factors in High-Rise Building Projects: A Survey in Vietnam. KSCE Journal of Civil Engineering, 18(4), pp. 865-874.

Kofoworola, O.F., \& Gheewala, S.H. (2009). Estimation of construction waste generation and management in Thailand. Waste Management, 29(2), pp. 731-738.

Kong, C. W., Li, H., \& Love, P. E. D. (2001). An e-commerce system for construction material procurement. Construction Innovation, 1(1), pp. 43-54.

Lau, H.H., Whyte, A., \& Law, P.L. (2008). Composition and characteristics of construction waste generated by residential housing project. International Journal of Environmental Research, 2(3), pp. 261-268. 
Lu, W., Yuan, H., Li, J., Hao, J. J., Mi, X., \& Ding, Z. (2011). An empirical investigation of construction and demolition waste generation rates in Shenzhen city, South China. Waste management, 31(4), pp. 680687.

Marinelli, M., Dolan, M., Spillane, J., \& Konanahalli, A. (2014). Material waste in the Northern Ireland construction industry: On-site management, causes and methods of prevention. In: Raiden, A B and Aboagye-Nimo, E. (Eds.). Proceedings of 30th Annual ARCOM Conference, 1-3 September 2014, Portsmouth, UK, Association of Researchers in Construction Management, 113-122.

Medina, C., Zhu, W., Howind, T., de Rojas, M. I. S., \& Frías, M. (2014). Influence of mixed recycled aggregate on the physical-mechanical properties of recycled concrete. Journal of Cleaner Production, 68(2014), pp. 216-225.

Morris, J. (ed.) 1999. Practical Recycling Economics: Making the Numbers Work for Your Program. Rutgers: The state university of New Jersey.

Moustakas, C. (1994). Phenomenological research methods. Thousand Oaks: Sage Publications.

Muhwezi, L., Chamuriho, L. M., \& Lema, N. M. (2012). An investigation into materials wastes on building construction projects in Kampala-Uganda. Scholarly Journal of Engineering Research, 1(1), pp. 11-18.

Nagapan, S., Rahman, I.A., Asmi, A., Memon, A.H, \& Zin, R.M. (2012). Identifying causes of construction waste - Case of central region of Peninsula Malaysia. International Journal of Integrated Engineering, 4(2), pp. $22-28$

Osmani, M. (2013). Design waste mapping: A project life cycle approach. Proceedings of the ICE-Waste and Resource Management, 166(3), pp. 114-127.

Osmani, M., Glass, J. \& Price, A.D.F. (2008). Architects' perspectives on construction waste reduction by design. Waste Management, 28(7), pp. 1147-1158.

Oyedele, L. O., Ajayi, S. O., \& Kadiri, K. O. (2014). Use of recycled products in UK construction industry: An empirical investigation into critical impediments and strategies for improvement. Resources, Conservation and Recycling, 93(2014), pp. 23-31.

Oyedele, L.O., Regan, M., Meding, J.V., Ahmed, A., Ebohon, O.J., and Elnokaly, A., 2013. Reducing waste to landfill in the UK: identifying impediments and critical solutions. World Journal of Science, Technology and Sustainable Development, 10(2), pp. 131 - 142.

Polkinghorne, D. E. (1989). Phenomenological research methods. In: Hailing, S., \& Valle, R. (1989). Existential-phenomenological perspectives in psychology, pp. 41-60. New York: Springer.

Poon, C.S., Yu, A.T.W., \& Ng, L.H. (2001). On-site sorting of construction and demolition waste in Hong Kong. Resources, Conservation and Recycling, 32(2), pp. 157-172

Porter, S., Tan, T., Tan, T., \& West, G. (2014). Breaking into BIM: Performing static and dynamic security analysis with the aid of BIM. Automation in Construction, 40(2014), pp. 84-95.

Read, A.D., Phillips, P., and Robinson, G., 1997. Landfill as a future waste management option in England: The view of landfill operators. Resources, Conservation and Recycling, 20(3), pp. 183-205 
Saez, P. V., del Río Merino, M., González, A. S. A., \& Porras-Amores, C. (2013). Best practice measures assessment for construction and demolition waste management in building constructions. Resources, Conservation and Recycling, 75(2013), pp. 52-62.

Sassi, P., \& Thompson, M.W. (2008). Summary of a study on the potential of recycling in the building industry and the development of an indexing system to assess the suitability of materials for recycling and the benefits from recycling. London: University of East London.

Skoyles, E. R. (1976). Materials wastage-a misuse of resources. Batiment International, Building Research and Practice, 4(4), 232-232.

Skumatz, L.A., 2008. Pay as you throw in the US: Implementation, impacts, and experience. Waste Management, 28(12), pp. 2778-2785.

Solís-Guzmán, J., Marrero, M., Montes-Delgado, M.V., \& Ramírez-de-Arellano, A. (2009). A Spanish model for quantification and management of construction waste. Waste Management, 29(9), pp. 2542-2548

Tam, V.W.Y. (2008). On the effectiveness in implementing a waste-management-plan method in construction, Waste Management, 28(6), pp. 1072-1080.

Tam, V.W.Y., Tam, C.M., Zeng, S.X., \& Ng, C.Y. (2007b). Towards adoption of prefabrication in construction. Building and Environment, 42(10), pp. 3642-3654.

Udawatta, N., Zuo, J., Chiveralls, K., \& Zillante, G. (2015). Improving waste management in construction projects: An Australian study. Resources, Conservation and Recycling, 101 (2015), pp. 73-83.

Umar, U.A., Shafiq, N., Malakahmad, A., Nuruddin, M.F. and Khamidi, M.F., 2016. A review on adoption of novel techniques in construction waste management and policy. Journal of Material Cycles and Waste Management, doi:10.1007/s10163-016-0534-8

Van Manen M. (1990). Researching lived experience: Human science for an action sensitive pedagogy. London, Ontario: Althouse.

Wang, J. Y., Kang, X. P., \& Wing-Yan Tam, V. (2008). An investigation of construction wastes: An empirical study in Shenzhen. Journal of Engineering, Design and Technology, 6(3), pp. 227-236.

Wang, J., Li, Z. and Tam, V.W., 2014. Critical factors in effective construction waste minimization at the design stage: a Shenzhen case study, China. Resources, Conservation and Recycling, 82, pp.1-7.

Wang, J., Li, Z., \& Tam, V. W. (2014). Critical factors in effective construction waste minimization at the design stage: a Shenzhen case study, China. Resources, Conservation and Recycling, 82, 1-7.

Wang, J., Li, Z., \& Tam, V. W. (2015). Identifying best design strategies for construction waste minimization. Journal of Cleaner Production, 92, 237-247.

WRAP, (2007). "Achieving effective waste minimisation through design: Guidance on designing out waste for construction clients, design teams and contractors" (online). Available at: http://www2.wrap.org.uk/downloads/Design_FINAL.67813ab5.4821.pdf. [Accessed: 1 $^{\text {st }}$ March, 2014].

WRAP, (2009a). "Designing out waste: A design team guide for buildings" (online). Available at: http://www.modular.org/marketing/documents/DesigningoutWaste.pdf. [Accessed: $3^{\text {rd }}$ March, 2014] 
Yeheyis, M., Hewage, K., Alam, M.S., Eskicioglu, C., \& Sadiq, R. (2013). An overview of construction and demolition waste management in Canada: A lifecycle analysis approach to sustainability. Clean Technologies and Environmental Policy, 15(1), pp. 81 - 91.

Yuan, H. (2013). Critical management measures contributing to construction waste management: Evidence from construction projects in china. Project Management Journal, 44(4), pp. 101-112. 